\title{
Integrating Green Fiscal Reforms into the Agricultural Transformation Agenda: Panacea for Boosting Soil Enrichment and Water Conservation for Sustainable Food Production in Nigeria
}

\author{
By L. O. Okojie ${ }^{1}$, R. A. Sanusi ${ }^{1}$, A. R. Popoola ${ }^{2}$
}

\begin{abstract}
Nigeria had a booming agricultural industry and prominent world market shares in many of its commodities at independence. With the continuous decline in these, the Agricultural Transformation Agenda (ATA) has been floated to promote twelve commodities in production along their value chains. Various innovations and expected benefits feature in the programme. The cultivation methods and other activities within the nodes of the value chains do not however specify green growth strategy promoted by green fiscal reform policies. This implies the shortchanging of green growth strategy in the national development process and so the compromising of sustainability. This paper valued the environmental services loss resulting from deforestation associated with "slash and burn" arable crop expansion and the benefits of "green grabbing" - the deliberate appropriation of nature in the ATA. The profitability of food crop production with and without green fiscal reform policies integration was also assessed. Sampling procedures that included the stratified, simple random and purposive sampling were used at various stages depending on the objective. Primary data were collected through structured questionnaire. The analytical tools adopted were the Contingent Valuation Method (CVM) of the referendum type, on-day site travel cost method and the budgetary analysis. Results showed that $66.37 \%$ forest land use changes occurred in a seven year periods for arable food crops expansion. The environmental services loss as depicted by the Willingness To Pay (WTP) was averagely N0.60billion/year. The stock recreation value derived from "green grabbing" for the same period with $5 \%$ of the Nigerian population of 150 million visiting the Obudu Mountain Resort (OMR) for recreational purposes considered was N4.41 x 1012 million. The recreation use benefits of the OMR based on the Marshalian consumer surplus computation was slightly higher for the same period. Profitability in food crop production without green fiscal reforms was higher as compared to when it was considered. This will encourage the food crop farmers to engage in actions that are inimical to environmental sustainability in the ATA. Sustainability of farming livelihood is therefore more likely to be ensured with green fiscal reform policy instruments integrated into the ATA. The ATA therefore cannot be sustainable under the current "business as usual" practice of "slash and burn" agriculture. The need to integrate green fiscal reform policies into the agenda therefore is urgent.
\end{abstract}

Keywords: Sustainability, deforestation, green growth, value chain analysis, green fiscal reform, Willingness To Pay, Marshalian consumer surplus.

\section{Introduction}

Nigeria had a booming agricultural industry at independence. Groundnut, palm oil, cocoa and cotton were the major focal points of the agricultural export drive that constituted the main stay of the economy. Nigeria has since suffered a decline in the production and loss of her major world market shares in all these commodities. The leading role of controlling groundnut

${ }^{1}$ Dept. of Agricultural Economics and Farm Mgt., Federal University of Agriculture, P.M.B. 2240, Abeokuta, Nigeria

${ }^{2}$ Dept. of Crop Protection, Federal University of Agriculture, P.M.B. 2240, Abeokuta, Nigeria 
world market share of $42 \%$ in 1961 according to the Federal Ministry of Agriculture and Rural Development Agricultural Transformation Agenda blueprint (www.unaab.edu.ng/attachments/) has since been eclipsed by China, United States of America and Argentina. The 27\% world market share of palm oil has equally been lost to Indonesia and Malaysia while the $18 \%$ world market share of cocoa and that of $1.4 \%$ share for cotton have equally been lost to Cote d'voire and Ghana for the former and to Mali and Burkina Faso in West Africa for the latter. The advent and exploration of crude petroleum for export played a major role here. The "old faithful" agriculture was relegated to the background. In addition, were the lack of strong marketing organizations linking farmers to the markets, fertilizers, credit, and rural infrastructure. While these are not in dispute, it can however be asserted that the advent of the "oil rigs" in the landscapes of Nigeria led to the non-proper articulation of how to move the agricultural sector to a more prosperous frontier. The new reality of the economic uncertainty in the oil sector has made the country to start looking back again to agriculture with the floating of a very ambitious development programme termed the Agricultural Transformation Agenda (ATA). Execution of this agenda has started with the promotion of twelve commodities in production (i.e. rice, cassava, sorghum, cocoa, cotton, maize, dairy, beef, leather, poultry, oil palm and fisheries) along their value chains. Government has divested itself under the Growth Enhancement Support Scheme (GESS) of the programme from procurement and distribution of fertilizers and other inputs and replaced them with a smart subsidy termed the "e-wallet" approach. Registered farmers under this programme by mere alerts on their mobile phones are connected to the warehouses where they can easily collect their subsidized agricultural inputs. Staple Crops Processing Zones (SCPZs) establishment focused on attracting private sector agribusinesses to set up processing plants in zones of high food production and process commodities into food products are being encouraged. This encouragement is emphasized by government putting appropriate fiscal, investment and infrastructural policies in place. These include tax breaks on imports of agricultural processing equipments, tax holidays for food processors located in these zones and supportive infrastructure in form of roads, logistics, storage facilities, power, flood control facilities, rail lines and airports. These SCPZs are expected to link food producers to the food manufacturers. Some of the world's biggest processing companies are planning to participate in them. Strengthening private sector driven marketing corporations is also another feature in the ATA blueprint. The Nigeria Incentive-Based Risk-Sharing System for Agricultural Lending (NIRSAL) is yet a new innovative mechanism in the ATA targeted at de-risking lending to the agricultural sector and bringing about the interdependence of the agricultural value chain and the agricultural financing value chain. In addition, is the establishment of the Agricultural Transformation Implementation Council (ATIC) that puts the nation's President/Vice President at the helm of affairs with other well meaning individuals from the public and the private sectors as members. This council sits at the apex of the programme while the Federal Ministry of Agriculture and Rural Development (FMARD) is at the centre stage for coordination. Included in the implementation groups also are the Agricultural Investment Transformation Implementation Group (AITEG), Agricultural Value Chain Implementation Group (AVCTEG), NIRSAL Implementation Group and the Agricultural Industry Advisory Group. These all play major roles and responsibilities in achieving the goal of the transformation agenda.

It is projected that with N60billion injection to execute the cassava agenda, Nigeria as a country would be able to substitute $20 \%$ of bread wheat with cassava flour and with the turning of cassava into a major export crop, an annual turnover of N40billion would be realized in addition to generating 1.2 million jobs. This is based on projected yield of 25 metric tonnes per hectare in 2015 from the 12.5 metric tonnes in 2010. In this line, yield of cocoa is expected to rise from $300 \mathrm{~kg} / \mathrm{ha}$ to $500 \mathrm{~kg} / \mathrm{ha}$ with a job creation of 360,000 and sorghum from 0.75 metric tonnes/ha to 2.5 metric tonnes/ha with associated job creation of 150,000. These conjectures would have been 
claimed to be quite inclusive and impressive especially with $20 \%$ cassava flour already being substituted for wheat flour in bread by the flour mills in Nigeria, but for the sustainability considerations. The cultivation methods of these commodities and other activities within the nodes of the value chains do not specify green growth strategy that evolves from green fiscal reforms implementation. Green fiscal reform in effect means "green tax shift" and the concept of a green tax shift implies reduction in the levying of taxes on the things that are valued by the society like jobs, incomes and profits and the lost revenue being replaced by levying taxes on things that the society does not like such as pollution and environmental degradation (Green Fiscal Commission Report, 2009). A political formulation puts it as "Pay as you burn, not pay as you earn". The "slash and burn" agricultural cultivation method is still the norm in agricultural farm production and there is nowhere in the ATA blueprint where low carbon input fertilizers are emphasized. Green growth which is a means of fostering economic growth and development while ensuring that natural assets continue to provide the resources and environmental services on which our well-being relies (OECD, 2011) is not promoted. This implies the shortchanging of sustainability in the national development process in the ATA. The World Commission on Environment and Development (1987) in the Brundtland report titled "Our Common Future" gives a clear meaning of the concept of sustainability - "meeting the needs of the present without compromising the ability of the future generation to meet their own needs". This is more succinctly explained from economic point of view by Mayor (1988) who attested to it meaning "living-off the earth's interest without encroaching on the capital" or "investing to sustain and enhance resource and ecological capital so that future dividends can be ensured and enlarged." The food crop cultivation method and all activities within the nodes of the value chains in the ATA do not seem to conform to the goal of sustainability. The non-inclusion of the Federal Ministry of Environment as a direct organ in the ATIC of the ATA but as one that can be consulted like some other non-essential ministries with respect to agricultural production further justifies that the issue of sustainability in the ATA blueprint was never "a card" on the table. There is the urgent need to reverse this to meet the lofty vision of the ATA to achieve a hungerfree Nigeria through an agricultural sector that drives income growth, accelerate achievement of food and nutritional security, generate employment and transform the country into a leading player in global food markets to grow wealth for farmers. This reverse can be effected by integrating into the ATA green fiscal policy reforms of government to eradicate the rudimentary "slash and burn" agriculture and other "business as usual" practices inimical to environmentally sound and sustainable development.

It is on the above basis, this paper investigates the following:

(i) Economic valuation of environmental services loss accruing with green fiscal policy reforms not integrated into the ATA.

(ii) Assessment of the values and benefits of "green grabbing" (i.e. the deliberate intervention to keep some land uses in their natural states) being incorporated into the ATA.

(iii) Comparative assessment of profitability with and without green fiscal reforms integration into the ATA.

\section{Methodology}

\subsection{Study Area}

The study area consisted of two states selected purposively from the twelve states of the Southwest and South-South geopolitical zones of Nigeria. The states are Ogun in the Southwest and Cross River in the South-South geo-political zones. They were selected for the forest reserves and deforestation in Ogun state and the "green grabbing" or deliberate intervention to keep land uses in their natural state as exemplified by the OMR in Cross River state. Ogun State lies 
between longitude $2^{\circ} 45^{\prime} \mathrm{E}$ and $3^{\circ} 55^{\prime} \mathrm{E}$ and latitude $7^{\circ} 0^{\prime} \mathrm{N}$ and $7^{\circ} 18^{\prime} \mathrm{N}$ and has an area of $16,085 \mathrm{~km}^{2}$ and a population of 3.25 million inhabitants (Omotayo, 2003). The Obudu Mountain Resort (OMR) is located in the highlands of Cross River State. The rainforest that undergoes land use change for agricultural expansion is the largest ecological belt that runs through each of the study areas.

\subsection{Sampling Techniques and Sample Size}

The multi-stage sampling technique was used in selecting the 260 respondents in the cross-sectional survey carried out in Ogun State. The first stage involved stratifying the study area into four zones Abeokuta, Ijebu Ode. Ikenne, and llaro based on the zonal structure of the Ogun State Agricultural Development Programme (OGADEP). The second stage involved the random selection of a number of blocks based on probability proportionate to size. In this sense, three blocks were randomly selected where there were six or more in each zone while two were randomly selected where five or less existed. These resulted in 26 extension cells. Ten respondents were randomly drawn from each cell to bring the total sample size $(\mathrm{N})$ for the Dichotomous-Choice Contingent Valuation Method (DC-CVM) component of the crosssectional survey to be two hundred and sixty (260) respondents.

Purposive sampling technique was used to select the tourists in the OMR and the sample size based on the emphasis on survey being focused on those who stay for at least one night and above in the park was 200 respondents. This was applied to assess the travel costs that individual visitors incurred in the ranch.

\subsection{Data Sources and Collection}

The data for this study were derived from primary and secondary sources. The primary data for Ogun state were derived from the contingent valuation based cross sectional survey administered questionnaire. This provided the data for the valuation of the environmental service functions of rainforest protection. The secondary data for this study area were obtained from the Ogun State Ministries of Forestry and Agriculture respectively, the Bureau of Land and Survey, the National Population Commission, and the Forest Management, Evaluation and Coordination Unit (FORMECU) of the Federal Department of Forestry. The primary data involved an openended CV format pre-test survey that helped to work out the bid amounts elicited in the actual DC-CVM cross-sectional survey. The goal was to ask how much the respondents were willing to pay if necessary to ensure that the productive and environmental services loss resulting from forest land use changes were abated (mitigated). The respondents were shown two sets of imageries in photographs. The first set depicted deforested environmental scenes and the second showed "lush" green rainforests and they were intimated of the environmental welfare loss resulting from such deforestation. This was to properly inform them on what they were being expected to value through the elicitation of their WTP following McCollum and Boyle (2005). The forest-reserved areas in their individual areas were used as the reference points. The verbal protocol and retrospective reporting following Lazo et al. (1992) was adopted. This involved recording the respondents' communication into a tape recorder continuously as to how much they were willing to pay as they looked at the two sets of imageries presented of the two scenarios of forestland uses and as they responded to additional predetermined prompts. The data so generated were used to work out the bid vectors $\left(b_{1}, b_{2}, \ldots, b_{m}\right)$ and the unique bid amounts $\left(* b_{1}\right.$, ${ }^{*} \mathrm{~b}_{2}, \ldots,{ }^{*} \mathrm{bm}$ ) following Bergland et. al (1987) with the former and Cooper (1993) with the latter. The 10 bid amounts so selected were used in the actual DC-CVM survey. This survey was carried out by administering randomly the various unique bid amounts among the various respondents in the 26 sampled extension cells in the study area following the worked out sample allocation to each bid value (i.e. $b^{*}{ }_{1}{ }^{*}{ }_{1}, b^{*}{ }_{2}{ }^{*}{ }_{2}, \ldots, b{ }_{2}{ }^{*}{ }_{2}, \ldots . ., b^{*}{ }_{m} n^{*}$ ). The administered bid amounts elicited 
the respondent willingness to pay (yes/no) for rainforest protection. The known areas of forest reserves in each area of study that could easily be visualized were used. These were then prorated to the deforested areas for the extensive food crop production as acquired from the remote sensing data derived from the project carried out for FORMECU of the Federal Department of Forestry by Geomatics of Canada. This was augmented by the data from the FAO projection of forest areas converted to the major alternative land use of food crop production in study area to the year 2004.

The Obudu Mountain Resort (OMR) which like many others would have been completely cleared under the rudimentary "slash and burn" cultivation method of the ATA was used for the analysis of "land grabbing" i.e. area purposively allocated to recreational areas. The essence was to determine the recreational value and the benefits of the resort that would have been lost without green fiscal reform policy of "land grabbing". The primary data were obtained from an on-site inquiry by questionnaire to tourist of 18 years and over. Of the 200 questionnaire distributed over the period of survey, 172 were used. The count data distribution model was used to get the number of recreation days a visitor stayed per visit to the resort. Individual on-site observation method was used to get information on the socio-demographic characteristics of the tourists, site perception and number of substitutes sites available. The visitor's geographical area was considered as the place he/she was when he/she decided to travel to the ranch. This was to overcome the multi-destination trip problems.

\subsection{Analytical Techniques}

A combination of analytical tools that include the non-market technique of referendum contingent valuation, binary logit regression model, the travel cost method and the budgetary analysis were used for this paper. The contingent valuation technique was used to value the identified environmental service functions of the forest loss that would have been protected if green fiscal reforms to promote green growth strategy within the ATA were put in place using the Willingness To Pay (WTP) concept. The maximum likelihood estimate of the logit regression model provided the coefficients necessary to compute the environmental service values loss. The logit regression model is based on Hanemann (1984) Approach as used by Cooper and Loomis (1992), Turcin and Giraud (2001) and Okojie and Akinwumi (2011) and it is as follows:

$P_{i}=\frac{1}{\left[1+e^{-(\alpha+\beta i x i)}\right]}$

Where:

$\mathrm{Pi}=$ Respondents acceptance probability to the bid offered.

$\beta i=$ Vector representing the coefficients of all covariates including that of the bid (B1)

$\mathrm{Xi}=$ Vector representing all covariates including that of the bid (X1)

$\mathrm{X}_{1}=\mathrm{Bid}$ offered to the respondents, which is what they are willing to pay (Naira)

$\mathrm{X}_{2}=$ Respondents Income (Naira)

$\mathrm{X}_{3}=$ Educational level attained (Years)

$\mathrm{X}_{4}=$ Household size (Number)

$\mathrm{X}_{5}=$ Sex dummy $(1=$ if male, $0=$ female $)$

$\mathrm{X}_{6}=$ Cost sharing dummy $(1=$ Support for developed countries sharing from the cost of taungya practices in developing countries for the environmental benefits, $0=$ If not)

$\mathrm{X}_{7}=$ Farmers years of experience $(1=$ If less than 10 years, $0=$ If more than 10 years $)$

$\mathrm{X}_{8}=$ Contact with extension agent $(1=$ If yes, $0=$ If not $)$

$\mathrm{X}_{9}=$ Immigrant status dummy ( 1 = If migrant, $0=$ non migrant $)$

The environmental service values of the forest loss were computed based on the restricted mean WTP following Cooper and Loomis (1992). The procedure is as follows:

$\mathrm{P}^{-}=1 /\left|\beta_{1}\right| * \ln (1+\exp \alpha)$

Where:

$\mathrm{P}^{-}=$restricted mean WTP,$\quad \alpha=$ intercept,$\quad \beta_{1}=$ coefficient of bid

The on-site individual observation Travel Cost Method (TCM) was used to derive the recreation 
value and benefits derivable but stand lost without "green grabbing" provision through green fiscal reform policies integration in the ATA. The truncated Poisson regression was used to derive the coefficients necessary for their estimations. The on-site TCM empirical approach following Mendes and Proneca (2005) was used to estimate the recreation demand function. The dependent variable was the number of days on-site..

The general specification of the TCM is as follows:

$\mathrm{DRP}_{\mathrm{i}}=\mathrm{f}\left(\right.$ Price, Income, Individual characteristics, $\left.B, \mathrm{e}_{\mathrm{i}}\right)$

Where:

$D R P_{i}=$ recreation days spent by a visitor in the ranch; $\beta=$ vector of parameters; $e_{i}=$ random disturbance that is independent from the disturbance of other individuals.

The recreation demand was modeled as the number of days one visitor stayed in the ranch $\left(\mathrm{DRP}_{\mathrm{i}}\right)$ at the time of the questionnaire. By choosing the semi-log form as commonly used to specify count data recreation demand models (Grogger and Long, 1994; Shaw, 1988; Okojie and Amujo, 2011), expected on-day site demand equation is specified as follows:

$\mathrm{E}\left(\mathrm{DRP}_{\mathrm{i}}\right)=\lambda_{1}=\exp \left(\beta_{0}+\beta_{1} \mathrm{CDRPi}+\beta_{2} \mathrm{YRi}+\beta_{3} \mathrm{IDi}+\beta_{4} \mathrm{EDi}+\beta_{5} \mathrm{FSi}+\beta_{6} \mathrm{Pi}+\beta_{7} \mathrm{Si}\right) \ldots$ (4)

This can be written as:

In $\lambda=\left(\beta_{0}+\beta_{1} \mathrm{CDRPi}+\beta_{2} \mathrm{YRi}+\beta_{3} \mathrm{IDi}+\beta_{4} \mathrm{EDi}+\beta_{5} \mathrm{FSi}+\beta_{6} \mathrm{Pi}+\beta_{7} \mathrm{Si}\right)$

Where:

$\mathrm{CDRPi}=$ Cost of one day of stay (Naira); YRi= Tourist income (Naira); IDi = Age (years)

$\mathrm{EDi}=$ Level of Education (Years spent in school); FSi= Family size of the tourist

$\mathrm{Pi}=$ The perception the visitor has of the ranch (binary variable; $1=$ satisfactory, $0=$ otherwise)

$\mathrm{Si}=$ Substitute site to $\mathrm{OMR}(1=$ If available, $0=0$ therwise $)$

The cost of one day stay in the ranch (in Naira) was calculated as follows:

$\mathrm{CRDPi}=\mathrm{CVi} / \mathrm{NDEi}+\mathrm{CNDEi}+\mathrm{CT}_{\mathrm{V}} \mathrm{i}+\mathrm{CT} \mathrm{i}+\mathrm{RUD}$.

Where:

$\mathrm{CVi}=$ Round travel cost in Naira; NDEi $=$ Number of days spent by individuals in the resort.

$\mathrm{CNDEi}=$ Cost of each day stay in the resort (Naira); CT $\mathrm{vi}$ and CTei $=$ Opportunity cost in Naira of travel and on-site stay time per visitor per day; RUD = Ranch entrance fee.

CTvi and CTei were quantified using one-third of individuals wage rate following Bocksteal et al. (1987) and Chakraborty and Keith (2000).

The log-likelihood estimation of the truncated Poisson regression of the on-day site demand equation provided the regression coefficients with which in addition to the covariate parameters means, the on-day site recreation demand was determined. These were also used to estimate the welfare measures (consumer surplus and WTP). The representative visitor's consumer surplus (CS) per each average day of stay visit was measured following Bocksteal et al. (1987) as follows:-

$\mathrm{CS}=-1 / \beta_{1}$

The Consumer Surplus Marshallian welfare measure is the money measure of the representative visitors benefit related with the use of the park ( $\mathrm{ranch}$ ) to produce recreation activities per each average day of stay visit. The visitor's Hicksian welfare measure of one average length day-of-visit with a semi-logarithmic form demand function is given following Bocksteal et. al (1987) and Englin Shonkwiller (1995) as:

WTP $_{\mathrm{s}}^{\mathrm{E}}=-1 / \beta_{2} \operatorname{In}\left(1+\lambda \beta_{2} / \beta_{1}\right)$

Where:

$\beta_{1}=$ Estimated parameter of price/recreation cost of the recreation demand function.

$\beta_{2}=$ Estimated income parameter

$\lambda=$ mean number of days stay in the resort.

When this mean or this set of individual welfares is aggregated across the entire sampled visitors) assuming that all behave like the representative one, total recreation value (TRV) at a single moment $(t=0)$ is:

$\operatorname{TRV}^{\mathrm{t}}=0=\mathrm{WTP}_{\mathrm{S}} \mathrm{Et}=0 \times \mathrm{N}$

Where: 
$\mathrm{N}=$ Average number of individuals that visit the park.

$\mathrm{WTP}_{\mathrm{S}} \mathrm{Et}=0=$ mean WTP (recreation value to the representative visitor for one average length day of stay in the park.

$\mathrm{TRV} t=0=$ present recreation value for one average length day of stay of all sampled visitors to the park.

This value when multiplied by the number of recreation days spent by sample visitors per year generated the total recreation value of the park per year.

The budgetary analyses for profit determination from cultivation of food crops under the ATA with and without green fiscal reform policies integration were considered. The present approach of "slash and burn" cultivation as prevails in the ATA was subjected to profit and profitability assessments and compared to where green fiscal reforms were integrated through taxation (environmental cost) of deforestation. The budgetary analysis was carried out for the former as below:

$\mathrm{GM}=\mathrm{TVP}-\mathrm{TVC}$

$\mathrm{NF} 1=\mathrm{GM}-\mathrm{TFC}$

Where:

$\mathrm{GM}=$ Gross margin; TVP $=$ Total value product; TVC $=$ Total variable cost.

TFC $=$ Total fixed cost NFI $=$ Net farm income.

In the case of the latter, it was computed as follows:

$\mathrm{GM}^{*}=\mathrm{TVP}-\left(\mathrm{TVC}+\mathrm{WTP}_{\mathrm{con}}+\mathrm{C}_{\mathrm{con}}\right)$

$\mathrm{NFI}^{*}=\mathrm{GM}^{*}-\mathrm{TFC}$

Where:

$\mathrm{GM}^{*}=$ Gross margin with green fiscal reforms (environmental taxation) considered .

$\mathrm{WTP}_{\text {con }}=$ Total WTP (total environmental service benefits) derived from rainforest conservation.

$\mathrm{C}_{\text {con }}=$ Total cost involved in rainforest conservation;

$\mathrm{NFI}^{*}=$ Net farm income with green fiscal reforms.

The profitability when green fiscal reforms were not integrated into the ATA (Equation 14) as compared to when it was (Equation 15) was assessed by the Rate of Return to Investment (RRTI) ratio as follows:

$\mathrm{RRTI}=\mathrm{NFI} / \mathrm{TC} \times 100$

$\mathrm{RRTI}^{*}=\mathrm{NFI}^{*} / \mathrm{TC}^{*} \mathrm{x} 100$

\section{Results and Discussion}

\subsection{Valuation of Environmental Services Loss from Deforestation for Agricultural Expansion}

Results show that 1,067,711 ha were deforested for arable crop expansion over a nine year period. This translated in 2004 to $66.37 \%$ deforested area for food crop production (Table 1). The total WTP was calculated from the relevant coefficients from the maximum likelihood estimate of the binary logit regression (Table 2). This value manifesting the environmental services loss was N17.28billion (i.e. N0.60billion/year) (Table 3). With green fiscal policies integration in the ATA, these environmental services can be harnessed. The trees that are cut down in the process of deforestation for arable crop cultivation through the rudimentary "slash and burn" cultivation method will remain to act as "carbon sink". This will go a long way to mitigating global warming and the associated climate change with the disastrous consequences. The trees that constitute the forest will help to reduce the impact of rain drops on the soil and so lead to less erosion and leaching of valuable nutrients. The effective coverage of the soil by the forest also will improve the watershed protection capability necessary for water availability to ensuring food security. The leaves, stems and twigs decay of the trees will serve to enrich the soil with nutrients and so enhance the capacity of the soil for increased food production. The oxygen released through respiration in plants in a green fiscal policy regime in the ATA will go a long way to serving as a source of life existence on earth. The "carbon sink" capability of such conserved 
forest will be enhanced and so serve to mitigate "green house" gas emission that facilitates climate change. These in essence are what are being lost at present as environmental services through massive deforestation for food crops expansion with green fiscal reforms that engender green growth strategy not emphasized in the ATA. This is a micro scale analysis with Ogun state which is just one out of the thirty six states and the Federal Capital Territory in Nigeria. They are partly what the environmental services valuation tends to capture in pecuniary terms and what stand to be gained with green fiscal reform policies integrated into the ATA.

\subsection{Recreation Use Values and Benefits of Obudu Cattle Ranch}

The recreation value and benefits derived from "green grabbing" as shown through a recreational resort (Obudu Mountain Resort) was computed from the coefficients derived from the truncated Poisson regression of the on-day site Travel Cost Method (TCM) (Table 4). The WTPE per tourist per day was N1,139.00 and this for a visit of three days per tourist to the ranch was N3,417.00. The WTPE for the 172 sample tourists to OMR per trip of three days is

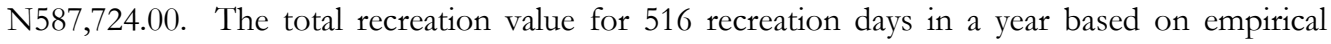
estimates yielded N101,088,528.00 (Table 4). This would vary from year to year depending on the number of visitors to the OMR and the number of days spent. This is a considerable amount per year in value for the 172 sampled visitors attached to the recreation use of OMR ecosystem. This is better understood if just 5\% of the Nigerian population of 150 million visits the OMR for recreational purpose. The stock recreation value will be N4.41 x $10^{12}$ million (Table 4). These are not derivable in the current ATA practices that do not give cognizance to inclusive green growth strategy that is engendered by the integration of green fiscal reform policies in production.

The recreation use benefits of the OMR calculated using the Marshalian consumer surplus for a representative visitor for each day of visit was N380.00 and for a visit of 3 days, this amounted

Table 1: Dominant Vegetation Types and Forest Land Use Changes to Food Crop Production (1976-2004)

\begin{tabular}{|c|c|c|c|c|c|}
\hline \multirow{2}{*}{$\begin{array}{l}\text { Vegetation Type and Land Use - } \\
1976\end{array}$} & \multirow[b]{2}{*}{$\begin{array}{l}\text { Area } \\
(\mathrm{Ha})\end{array}$} & \multicolumn{4}{|c|}{ Forest Land Use Conversion to Food Crop Production (Ha) } \\
\hline & & $1995(\mathrm{Ha})$ & $\begin{array}{c}\text { Proportion of } \\
\text { Conversion in } 1995(\%)\end{array}$ & $2004(\mathrm{Ha})$ & $\begin{array}{c}\text { Proportion of Conversion } \\
\text { in } 2004(\%)\end{array}$ \\
\hline Disturbed Forest & 132,700 & 27,000 & 20.35 & 29,378 & 22.14 \\
\hline Guinea Savannah & 112,800 & - & - & - & - \\
\hline Undisturbed Forest & 25,100 & - & - & - & - \\
\hline Riparian Forest & 29,500 & 27,900 & 94.58 & 27,936 & 94.70 \\
\hline Intensive Food Crop Agriculture & $1,162,300$ & $1,006,900$ & 86.63 & $1,010,397$ & 86.93 \\
\hline Others & 146,300 & - & - & - & - \\
\hline Total & $1,608,700$ & $1,061,800$ & 66.00 & $1,067,711$ & 66.37 \\
\hline
\end{tabular}

Table 2: Maximum Likelihood Estimations of Responses to Willingness-to-Pay (WTP) Questions and Estimation of Mean WTP.

\begin{tabular}{|c|c|c|c|c|c|}
\hline \multirow[b]{3}{*}{ Variables } & \multicolumn{5}{|c|}{ Study Area and Its Zones } \\
\hline & All Zones & Zone 1 & Zone 2 & Zone 3 & Zone 4 \\
\hline & $\begin{array}{l}\text { Coefficient } \\
\text { and Z-Value }\end{array}$ & $\begin{array}{l}\text { Coefficient } \\
\text { and Z-Value }\end{array}$ & $\begin{array}{c}\text { Coefficient and } \\
\text { Z-Value }\end{array}$ & $\begin{array}{c}\text { Coefficient and } \\
\text { Z-Value }\end{array}$ & $\begin{array}{c}\text { Coefficient and } \\
\text { Z-Value }\end{array}$ \\
\hline Constant $\left(\beta_{0}\right)$ & $\begin{array}{c}0.18 \\
(0.19)\end{array}$ & $\begin{array}{c}0.70 \\
(0.43)\end{array}$ & $\begin{array}{l}-1.83 \\
(-.86)\end{array}$ & $\begin{array}{l}-1.95 \\
(-0.44)\end{array}$ & $\begin{array}{c}-1.94 \\
(-0.50)\end{array}$ \\
\hline $\operatorname{Bid}\left(\beta_{1}\right)\left(X_{1}\right)$ & $\begin{array}{c}-0.0074 * * * \\
(-7.35)\end{array}$ & $\begin{array}{c}-0.011 * * * \\
(-3.84)\end{array}$ & $\begin{array}{c}-0.0053^{* * *} \\
(-.41)\end{array}$ & $\begin{array}{c}-0.14 * * * \\
(-2.79)\end{array}$ & $\begin{array}{c}-0.02^{* * *} \\
(-2.65)\end{array}$ \\
\hline
\end{tabular}




\begin{tabular}{|c|c|c|c|c|c|}
\hline Income $\left(\mathrm{X}_{2}\right)$ & $\begin{array}{c}0.13 * * * \\
(3.33)\end{array}$ & $\begin{array}{c}0.00020^{* * * *} \\
(2.98)\end{array}$ & $\begin{array}{c}0.000033^{*} \\
(1.84)\end{array}$ & $\begin{array}{l}0.00014 \\
(1.53)\end{array}$ & $\begin{array}{l}0.00032^{* *} \\
(2.28)\end{array}$ \\
\hline $\begin{array}{l}\text { Educational Level } \\
\text { (Dummy) }\left(\mathrm{X}_{3}\right)\end{array}$ & $\begin{array}{c}0.0063^{* * *} \\
3.40)\end{array}$ & $\begin{array}{c}0.37 \\
(0.39)\end{array}$ & $\begin{array}{l}0.18^{* *} \\
(2.23)\end{array}$ & $\begin{array}{l}0.42 * * \\
(2.36)\end{array}$ & $\begin{array}{c}0.30 \\
(1.45)\end{array}$ \\
\hline $\begin{array}{l}\text { Household Size } \\
\text { (Dummy) }\left(\mathrm{X}_{4}\right)\end{array}$ & $\begin{array}{l}0.0066 \\
(-0.084)\end{array}$ & $\begin{array}{l}-0.10 \\
(-0.56)\end{array}$ & $\begin{array}{c}0.17 \\
(0.15)\end{array}$ & $\begin{array}{c}0.24 \\
(0.76)\end{array}$ & $\begin{array}{c}0.35 \\
(0.86)\end{array}$ \\
\hline Sex 1 (Dummy) ( $\mathrm{X}_{5}$ ) & $\begin{array}{c}0.31 \\
(0.44)\end{array}$ & $\begin{array}{l}-0.11 \\
(-0.14)\end{array}$ & $\begin{array}{c}0.26 \\
(0.29)\end{array}$ & $\begin{array}{l}-1.64 \\
(-1.20)\end{array}$ & $\begin{array}{c}2.39 \\
(1.60)\end{array}$ \\
\hline $\begin{array}{l}\text { Tropical Deforestation } \\
\text { (Dummy) }\left(\mathrm{X}_{6}\right)\end{array}$ & $\begin{array}{l}-0.13 \\
(-0.36)\end{array}$ & $\begin{array}{c}0.95 \\
(1.04)\end{array}$ & $\begin{array}{l}-0.08 \\
(-0.13)\end{array}$ & $\begin{array}{l}-0.0029 \\
(-0.002)\end{array}$ & $\begin{array}{c}1.90 \\
(0.94)\end{array}$ \\
\hline $\begin{array}{l}\text { Rainforest visitor } \\
\text { dummy }\left(\mathrm{X}_{7}\right)\end{array}$ & $\begin{array}{c}-1.16 * * \\
(-2.18)\end{array}$ & $\begin{array}{l}-0.27 \\
(-0.21)\end{array}$ & $\begin{array}{l}-1.26 \\
(-1.23)\end{array}$ & $\begin{array}{l}-0.26 \\
(-0.21)\end{array}$ & $\begin{array}{l}-2.01 \\
(-0.70)\end{array}$ \\
\hline $\begin{array}{l}\text { Intergenerational Equity } \\
\text { dummy }\left(\mathrm{X}_{8}\right)\end{array}$ & $\begin{array}{c}0.87 \\
(1.40)\end{array}$ & $\begin{array}{l}-1.17 \\
(-0.82)\end{array}$ & $\begin{array}{c}2.67 * * \\
(1.98)\end{array}$ & $\begin{array}{c}0.61 \\
(0.26)\end{array}$ & - \\
\hline $\begin{array}{l}\text { Cost sharing dummy } \\
\left(\mathrm{X}_{9}\right)\end{array}$ & $\begin{array}{c}1.17 \\
(1.11)\end{array}$ & $\begin{array}{c}1.37 \\
(1.26)\end{array}$ & $\begin{array}{l}-0.78 \\
(-0.93)\end{array}$ & - & - \\
\hline $\begin{array}{l}\text { Immigrant status } \\
\text { dummy }\left(\mathrm{X}_{10}\right)\end{array}$ & $\begin{array}{c}-0.71 * * \\
(-2.00)\end{array}$ & $\begin{array}{c}-0.86 * * \\
(-1.04)\end{array}$ & $\begin{array}{c}-0.62 * * \\
(-0.99)\end{array}$ & $\begin{array}{l}-2.44^{*} \\
(-1.74)\end{array}$ & $\begin{array}{l}-2.89^{*} \\
(-1.49)\end{array}$ \\
\hline $\begin{array}{l}\text { Food crop producer } \\
\text { dummy }\left(\mathrm{X}_{11}\right)\end{array}$ & $\begin{array}{l}0.00012 * * * \\
\quad(3.05)\end{array}$ & $\begin{array}{c}0.014 * * * \\
(2.85)\end{array}$ & $\begin{array}{c}0.0032^{* * *} \\
(3.26)\end{array}$ & $\begin{array}{l}00047^{* *} \\
(2.01)\end{array}$ & $\begin{array}{c}0.0023 * * * \\
(2.93)\end{array}$ \\
\hline Number of observations & 260 & 80 & 80 & 50 & 50 \\
\hline Goodness of fit & Pseudo $\mathrm{R}^{2}=0.45$ & PseudoR $^{2}=0.48$ & $\begin{array}{c}\text { PseudoR }^{2}= \\
0.28\end{array}$ & $\begin{array}{c}\text { Pseudo } \mathrm{R}^{2}= \\
0.61\end{array}$ & $\begin{array}{c}\text { Pseudo } \mathrm{R}^{2}= \\
0.71\end{array}$ \\
\hline & $\mathrm{LR} \mathrm{X}^{2}=47.55^{* * *}$ & $\begin{array}{l}\text { LR X } X^{2}= \\
47.55^{* * *}\end{array}$ & $\mathrm{LRX}^{2}=29.86^{* * *}$ & $\begin{array}{l}\mathrm{LRX}^{2}= \\
38.67 * * *\end{array}$ & $\begin{array}{l}\mathrm{LR} \mathrm{X}^{2}= \\
47.23^{* * *}\end{array}$ \\
\hline Mean Willingness to Pay & $\begin{array}{c}\text { N552.50 } \\
\text { /household/ } \\
\text { month }\end{array}$ & $\begin{array}{c}\text { N51.31 } \\
\text { /household/ month }\end{array}$ & $\begin{array}{c}\text { N157.47 } \\
\text { /household/ } \\
\text { Month }\end{array}$ & $\begin{array}{c}\mathrm{N} 4.99 \\
\text { /household / } \\
\text { month }\end{array}$ & $\begin{array}{c}\text { N32.80 } \\
\text { /household/ } \\
\text { Month }\end{array}$ \\
\hline
\end{tabular}

*** Significant at 1\% level, **Significant at 5\% level, * Significant at $10 \%$ level

Source: Computed from Field Survey Data, 2004.

to $\mathrm{N} 1,140.00$. This for the 172 sample visitors was $\mathrm{N} 196,080.00$ and for 516 recreation days per year, it was N101,177,280.00 (Table 4). This implies the OMR visitors receive a considerable amount of benefit from the recreation use of the OMR ecosystem. This sort of benefit stands to be lost in an agricultural production system that does not emphasize a green growth strategy promoted by green fiscal reform policy instruments as currently obtains in the ATA where deliberate attempts are not emphasized for "land grabbing" to promote such facilities. These recreational value and benefits which are not easily quantified in market operations and are very necessary for life existence on earth as they touch on oxygen we breathe in, the carbon dioxide we breathe out, the soil and water conservation that enable sustainable food production and the invigorated state that keep us in good health to pursue economic activities. These are not what can easily be benefited from the cultivation procedure of massive deforestation manifested by the "slash and burn" cultivation method of the ATA - actions for which the culprit farmers ought to be fiscally punished through taxation. Without deliberate intervention to ensure "green grabbing" within the execution of the ATA blue print, these service functions provided by such areas would be lost. 
Table 3: Total Willingness to Pay Estimates Associated with Forest Land Use Conversion To Food Crop Production.

\begin{tabular}{|c|c|c|c|c|c|c|c|c|}
\hline Study Area & $\begin{array}{l}\text { Mean } \\
\text { Willingness- } \\
\text { to-Pay } \\
\text { (MWTP) } \\
\text { (N / } \\
\text { Household } \\
\text { / Month) }\end{array}$ & $\begin{array}{l}\text { Total } \\
\text { Household }\end{array}$ & $\begin{array}{l}\text { Total WTP } \\
\text { (N / Year) }\end{array}$ & $\begin{array}{l}\text { Total } \\
\text { Forest } \\
\text { Area } \\
(\mathrm{Ha})\end{array}$ & $\begin{array}{l}\text { WTP/Ha } \\
\text { for } \\
\text { Protection } \\
\text { of Forest } \\
\text { Reserved } \\
\text { Area } \\
\text { (N/ Year) }\end{array}$ & $\begin{array}{l}\text { Total Forest } \\
\text { Land Use } \\
\text { Conversion } \\
\text { to Food } \\
\text { Crop } \\
\text { Production } \\
(1976-2004) \\
(\mathrm{Ha})\end{array}$ & $\begin{array}{l}\text { Total WTP } \\
\text { Associated with } \\
\text { Forest Land use } \\
\text { Conversion to } \\
\text { Food Crop } \\
\text { Production in } \\
1976-2004 \\
(\mathrm{~N})\end{array}$ & $\begin{array}{l}\text { Total } \\
\text { WTP/Year } \\
\text { Associated with } \\
\text { Forest Land use } \\
\text { Conversion to } \\
\text { Food Crop } \\
\text { Production in } \\
1976-2004 \\
(\mathrm{~N})\end{array}$ \\
\hline $\begin{array}{l}\text { AllZones } \\
\text { (OgunState) }\end{array}$ & 552.50 & 666,909 & $4,421,606,670.00$ & $273,162.00$ & $16,186.76$ & $1,067,711.00$ & $\begin{array}{l}17,282,781,000.00 \\
(17.28 \text { billion })\end{array}$ & $\begin{array}{l}555,, 957,989.90 \\
(0.60 \text { billion })\end{array}$ \\
\hline
\end{tabular}

\subsection{Profitability in Farming Livelihood with and without Green Fiscal Reform Integration}

With green fiscal reforms considered in the ATA in Ogun state, the net farm income was found to be N52,919.52/ha (Table 5) which was lower than the N69,106.26/ha when it was not (table 6). The RRTI also followed the same trend in both cases $-30.1 \%$ in the former (Table 5 ) as compared to the $30.6 \%$ in the latter (Table 6). This implies greater tendency for the food crop farmers to engage in deforestation, degradation and other actions that are inimical to environmental sustainability in the ATA based on profitability considerations. This is especially as the farmers are not enforced to carry the additional burden of their cost of environmental damage. Sustainability of the livelihood of farming is therefore more likely to be ensured with green fiscal reforms policy instruments integrated into the ATA as compared to when it is not.

Table 4: Result of the Truncated Poisson Regression of On-Day Site Demand Ecotourism Model, Recreation and Recreation Use Benefits in Obudu Mountain Resort

\begin{tabular}{lccc}
\hline Variables & Coefficient & Z-Statistics & $\mathrm{P} / \mathrm{Z} /$ \\
\hline Constant & 0.3295795 & 0.56 & 0.575 \\
Cost (one day of stay) (CRDPi) & 0.00263 & 0.59 & 0.558 \\
Income (YRi) & 0.000013 & 3.30 & $0.001 * * *$ \\
Age(IDi) & 0.0007851 & 0.09 & 0.925 \\
Educational level(EDi) & 0.0217963 & 0.54 & 0.588 \\
Household size (FSi) & -0.0092878 & -0.24 & 0.807 \\
Perception (Pi) & 0.2071663 & 1.03 & 0.301 \\
Substitute site (Si) & -0.0253134 & -0.26 & 0.575 \\
No of observations & 172 & & \\
Pseudo R & 0.0428 & & \\
Log Likelihood & -275.54228 & & \\
Recreation value/year (Nmillion) & $101,088,528.00$ & & \\
Stock Recreation Value (5\% of Nigerian Population) (Nmillion) & $4.41 \times 10^{12}$ & & \\
Recreation use benefits/year (N million) & $101,177,280.00$ & & \\
\hline
\end{tabular}

*** Significant at $1 \%$ level

Source: Computed from Field Survey Data, 2008.

Table 5: Profitability Analysis in Food Crop Production without Green Fiscal Reform Instruments

\begin{tabular}{lcc}
\hline Cost, Revenue and Farm Income & $\mathrm{N}$ & $\mathrm{K}$ \\
\hline Total fixed cost & 33,626 & 33 \\
Total variable cost & 346,100 & 83 \\
Total cost & 379,727 & 26 \\
Total value product & 524,159 & 38 \\
Average Farm Size (Ha) & 2.09 & \\
Gross margin/Ha & 85,195 & 43 \\
Net Farm income/Ha & 69,106 & 28 \\
Rate of Return to cap0ital invested $(\%)$ & 38.04 & \\
\hline
\end{tabular}

Source: Computed from Field Survey, 2004. 
Table 6: Profitability Analysis in Food Crop Production with Green Fiscal Reform Instruments.

\begin{tabular}{lcc}
\hline Cost, Revenue and Farm Income & $\mathrm{N}$ & $\mathrm{K}$ \\
\hline Total fixed cost & 33,626 & 33 \\
Total variable cost & 346,100 & 83 \\
Environmental Cost of deforestation & 33,830 & 33 \\
Total cost & 413,557 & 59 \\
Total value product & 524,159 & 38 \\
Average Farm Size (Ha) & 2.09 & \\
Gross margin/Ha & 69,008 & 67 \\
Net Farm income/Ha & 52,919 & 52 \\
Rate of Return to capOital invested (\%) & 30.27 & \\
Source: Computed from Field Survey, 2004. & &
\end{tabular}

\section{Conclusion}

The ATA in Nigeria is an ambitious programme that aims to bring about food security and the lost glory in agriculture but the way it is being executed raises a lot of questions on the issue of sustainability of the programme. Deliberate efforts have not been made to integrate green fiscal reform policies to encourage a green growth strategy in the execution of the blueprint. These have led to intensive deforestation and degradation and so loss of environmental service benefits, situations that are not in agreement with environmental friendliness necessary to perpetuate the programme. This is further accentuated by the non-deliberate policy on the part of the government to engage in "land grabbing" to promote recreation and enhance environmental services necessary for life existence on earth within the ATA. The environmental service functions loss of not protecting our forests has been found to be of high magnitude in pecuniary terms. This is equally true when "forests grabbing" for recreation parks are not encouraged within the ATA. The monetary value and welfare benefits attached to these areas in addition to the essential services they provide for enhancing soil improvement and water conservation necessary for food crop production are lost. The non-integration of green fiscal reforms into food production has been found to be more profitable as compared to farming livelihoods that are so supported. The tendency here is the eagerness on the part of food crop producers to engage in their current unsustainable practices. This is because the environmental taxes considered here are not currently borne by the farmers in the ATA.

The policy implication is that ATA cannot be sustainable under the current "business as usual" and rudimentary "slash and burn" agricultural production system. It cannot be in a situation where policy makers erroneously think that "environment should only be protected when it does not impede developmental projects". Non-market benefits that are very beneficial to life existence on earth are lost when green fiscal policy reform instruments that will promote green growth strategies are not put in place in a project as ambitious as the ATA in Nigeria. The reduction of deforestation through agricultural expansion, encouragement of "land grabbing" for recreational parks establishment and other ecosystem conservation are some of the ways fiscal reform policies to promote inclusive green growth strategy can be integrated into the ATA. The agenda is already benefiting the confectionery industry as a result of $20 \%$ wheat flour substitution by cassava flour resulting in huge savings of foreign exchange. This calls for punitive green fiscal taxes to be imposed on those who pursue their sources of livelihood in ways that are inimical to environmentally sound and sustainable development while reducing the taxes to those engaged in beneficial environmentally friendly sources of livelihoods. This integration of green fiscal policy reforms into the ATA is very urgent to ensure sustenance of rural livelihoods as they relate to food production with respect to the conservation of soil and water. 


\section{References}

Agricultural transformation agenda: We will grow Nigeria's agricultural sector, Draft for Discussion, Federal Ministry of Agriculture, Abuja, $\quad$ pp $\quad$ http://www.unaab.edu.ng/attachments LAgricultural $\% 20$ Transformation $\% 20$ Blue $\% 20$ Print.pdf (accessed on $5^{\text {th }}$ June, 2013).

Bergland,O., Musser,W., Musser,I., K. Terry (1987). Optimal sampling intensities in close-ended contingent valuation methods. Draft Paper, Department of Agricultural Economics, Oregon State University, Corvallis, Oregon.

World Commission on Environment and Development (1987). Our common future: The Brudtland Report. Oxford University Press.

Bockstael, N., Hanemann, W.M. and I. Strand (1989). Measuring the benefit of waves quality improvements using recreation models. Vol II EPA-230-10-89-069. USEPA Washington D.C.

Chakraborty, K. and J. E. Keith (2000). Estimating the recreation demand and economic value of mountain mountain biking in Moab, Utah: an application of Count Data Models. Journal of Environmental Planning and Management, Vol. 43(4): 461-469.

Cooper, J. C. (1993). Optimal bid selection for dichotomous-choice contingent valuation surveys. Journal of Environmental Economics and Management, 24, 25-40.

Cooper, J.C. and Loomis, J. (1992). Sensitivity of willingness-to-pay to bid design in dichotomous choice contingent valuation models. Land Economics 68(2): 211-224.

Englin, J. and J.S. Shonkwiller (1995). Estimating social welfare using count data models: an application to long-run recreational demand under conditions of endogenous stratification and truncation. The review of Economic and Statistics, Vol. 77, p 104-112.

Fairhead, J., Leach, M. and I. Scoones (2012). Green grabbing: a new appropriation of nature. Journal of Peasant Studies, Vol. 39(2): 237-261.

FORMECU (1995). The assessment of land use and vegetation changes in Nigeria between 1976 and 1993/95. Report of a Study submitted by Geomatics International, Ontario, Canada, p 55 - 56.

Green Fiscal Commission Report (2009). The Case for Green Fiscal Reform, Final Report of the UK Green Fiscal Commission.

Grogger, J. and R. Carson (1991). Models for truncated counts. Journal of Applied Econometrics, Vol. 6(3): 225-238.

Hanemann, W.M. (1984). Welfare evaluations in contingent valuation experiments with discrete responses. American Journal of Agricultural Economics, Vol. 66: 332-341.

Lazo, J. K., Schulze, W. D., G.H. McClelland, J. K. Doyle (1992). Can contingent valuation measure non-use values? American Journal of Agricultural Economics 74(5): 114-120.

Mayor, Federico (1988). Geographical information system for managing sustainable development: The UNESCO approach. ITC Journal 1988: 4.

McCollum, D. W., J. K. Boyle (2005). The effect of respondent experience/knowledge in the elicitation of contingent values: An investigation of convergent validity, procedural invariance and reliability, Environmental and Resource Economics 30 (1): 23-33.

Mendes, I. and I. Proneca (2005). Estimating the recreation value of ecosystems by using travel cost method approach, Working Paper presented to the permanent seminar of the Department of Economics, Technical University of Lisbon.

NPC (National Population Commission) (2006). Nigeria National Population Census. NPC, Abuja.

OECD (2011). Towards Green Growth, OECD, Paris.

Okojie, L. O. and J. A. Akinwumi (2011). Monetizing the environmental welfare impact of deforestation in Ogun State, Nigeria: The Contingent Valuation Approach, Asian Journal of Water, Environment and Pollution, 8(2): 83-92, IOS Press, Amsterdam.

Okojie, L. O. and B. T. Amujo (2011). Socio-economic determinants of on-day site demand for recreation in Old Oyo National Park, Nigeria, Journal of Development and Agricultural Economics, 3, (6): 230-235, Academic Journals.

Omotayo, A. M. (2003). Biological implications of fulbe pastorialism in Southwestern Nigeria. Land Degradation \& Development 14: 445-457.

Shaw, D. (1988). On-site samples regression: problems of non-negative integers, truncation and endogenous stratification. Journal of Econometrics, Vol. 37: 211-223.

Turcin, Branka and Giraud, Kelly (2001). Contingent valuation willingness to pay with respect to geographically nested samples: Case study of Alaskan Steller Sea Lion.. 2001 W-133 Western Regional Project Technical Meeting Proceedings.

World Commission on Environment and Development (1987). Our Common Future: The Brundtland Report. Oxford University Press. 